\title{
KRUSTASEA ARAFURA SEBAGAI IDE PENCIPTAAN BATIK
}

\section{Arafura Crustaceans as An Idea for Batik Creation}

\author{
Farid Abdullah ${ }^{1}$, Theresia Widiastuti ${ }^{2}$, Bandi Sobandi ${ }^{1}$, dan Bambang Tri Wardoyo ${ }^{3}$ \\ ${ }^{1}$ Universitas Pendidikan Indonesia, JI. Dr. Setiabudhi 229, Bandung, Jawa Barat. \\ ${ }^{2}$ Universitas Sebelas Maret, jl. Ir. Sutami 36, Kentingan, Jebres, Surakarta, Jawa Tengah \\ ${ }^{3}$ Universitas Trisakti, Jl. Kiai Tapa no. 1, Jakarta Barat.
}

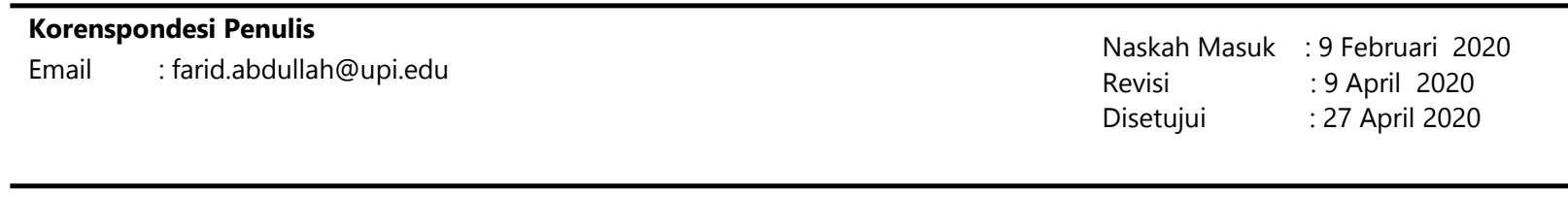

Kata kunci: batik, desain, kreativitas, krustasea, Arafura

Keywords: batik, design, creativity, crustaceans, Arafura

\begin{abstract}
ABSTRAK
Potensi sumber daya alam perikanan saat ini terus digali, namun mengubah potensi sumber daya alam menjadi penciptaan kreasi batik masih sangat terbatas. Tujuan tulisan ini adalah menghasilkan eksperimentasi berdasarkan sumber ide krustasea Arafura yang dikembangkan menjadi desain busana batik. Metode yang dipergunakan adalah deskriptif-eksperimentatif, memakai model 4-D Thiagarajan (1974) yaitu (1) Definisi; (2) Desain; (3) Pengembangan; dan (4) Diseminasi. Dimulai dengan mengidentifikasi potensi lokal Arafura, seleksi, merumuskan ide-ide, eksperimentasi, hingga penciptaan desain. Hasil dari eksperimen ini adalah purwarupa busana batik berdasarkan ide krustasea yang melimpah di Arafura. Kesimpulan berupa potensi ekonomi kreatif bersumber ide lokal sumber daya alam laut Arafura, dapat menambah nilai ekonomi bagi masyarakat setempat. Rekomendasi yang diberikan adalah terus menggali potensi-potensi alam lainnya yang terkait dengan sumber daya alam kelautan untuk diubah menjadi produk ekonomi kreatif.
\end{abstract}

\section{ABSTRACT}

The potential of fisheries resources has been explored continuously, but transforming the resources into creative idea of batik creation is still limited. This study aims to conduct experiment based on Arafura crustaceans, as an idea for batik fashion designs. The method used is descriptive-experimental method, using Thiagarajan 4D model (1974), namely (1) Definition; (2) Design, (3) Development; and (4) Dissemination. The study was started by identifying the local potential of Arafura, selection, formulating ideas, experiments, and creating the design. The result of this experiment is a prototype of batik clothes using design based on the idea of crustacean which is abundant in Arafura. The conclusion from this experiment is creative economic potential comes from local ideas of crustacean Arafura natural resources. The recommendation is to continue the exploration of other marine natural potentials resources as ideas for creative economic products. 


\section{PENDAHULUAN}

Indonesia adalah negara kepulauan yang terdiri dari 17.508 pulau, dengan total panjang garis pantai sekitar $81.000 \mathrm{~km}$ (Baransano dan Mangimbulude, 2011). Garis pantai yang panjang memiliki potensi sumber daya biologis, sumber daya buatan, dan layanan pariwisata yang sangat penting bagi kehidupan masyarakat pesisir (Wedjatmiko, 2010). Diperkirakan bahwa hampir $60 \%$ populasi Indonesia tinggal di wilayah pesisir (Arbi, 2008). Kelimpahan sumber daya air dapat memainkan peran ganda sebagai sumber daya yang mendukung kehidupan manusia, ekosistem perairan, dan sebagai komponen penting dari pembangunan ekonomi (Ibrahim, 2007). Wilayah laut Arafura di Indonesia Timur memiliki potensi sumber daya ide yang dapat diolah menjadi produk kreatif yang dicirikan potensi lokal.

Budayawan Edi Sedyawati menyatakan laut adalah faktor lingkungan yang memiliki pengaruh besar pada citra budaya suatu bangsa (Sedyawati, 2014). Kawasan laut termasuk potensi di dalamnya juga dapat mengangkat suatu identitas citra budaya setempat (Himawan, 2014). Pemanfaatan sumber daya laut di sekitar tanah tempat tinggal tentu dapat memiliki pengaruh sendiri pada orang-orang di unit sosial sekitarnya (Darsono, 1999). Pengaruhpengaruh ini dapat ditemukan di berbagai bidang kehidupan. Kedekatan laut dalam kehidupan manusia dapat membawa ke posisi penting, bahkan sentral, dalam pandangan kosmologis kelompok etnis yang bersangkutan
Laut Arafura terletak di timur Indonesia, di wilayah perairan antara Australia dan Pulau Papua, di kawasan Samudra Pasifik. Arafura adalah salah satu perairan yang mendapat julukan "The Golden Fishing Ground" industri perikanan Indonesia. Potensi berkelanjutan atau Maximum Sustainable Yield (MSY) Laut Arafura mencapai 771.600 ton / tahun yang terdiri dari berbagai ikan laut seperti pelagis, demersal, udang, cumi-cumi, lobster, dan ikan karang (Monintja, 2006). Laut Arafura telah menjadi faktor yang menarik bagi perikanan tangkap skala besar menggunakan kapal dengan berat lebih dari 30 ton. Kegiatan menangkap hasil laut dengan intensitas tinggi di Laut Arafura menyebabkan eksploitasi sumber daya alam yang berlebihan. Di sisi lain, Laut Arafura memberikan kontribusi signifikan di bidang ekonomi dan sangat penting untuk melibatkan berbagai disiplin ilmu seperti ekologi, ekonomi, sosial, etika (Mulyana, 2012) dan seni. Mengelola potensi Laut Arafura juga dituntut inovatif dengan meningkatkan potensi sumber daya lokal menjadi produk bernilai ekonomi kreatif.

Potensi krustasea di dunia sangat besar. Menurut peneliti kelautan dari Museum Sejarah Alam, Los Angeles, Joe L. Martin dan George E Davis, ada sekitar 52.000 spesies krustasea di dunia. Dari jumlah tersebut, dapat diklasifikasikan ke dalam 849 famili dalam 42 ordo dan 6 kelas (Martin dan Davis, 2001). Demikian juga krustasea di laut Arafura, Indonesia timur. Tangkapan udang di perairan Kepulauan Arafura menunjukkan bahwa ada 9 spesies udang penaeid, dengan krustasea dominan 
adalah udang bunga (Penaeus semisulcatus. L), sedangkan krustasea terendah adalah jerbung (Penaeus merguensis. L). Data ini menjelaskan potensi berlimpahnya krustasea di perairan laut Arafura (Hoek dkk., 2015). Pembudidayaan krustasea saat ini terbatas pada bahan makanan. Pengolahan kreatif krustasea saat ini relatif belum diolah secara kreatif inovatif, terutama menjadi motif pada produk batik.

Eksperimentasi untuk menghasilkan purwarupa (prototype) sesungguhnya banyak dilakukan para peneliti, seperti penciptaan berbasis budaya lokal pada suku Dani, Papua (Eskak dan Widiyastuti, 2019). Batik juga menghadapi identitas yang perlu dilakukan re-invensi (Moersid, 2013). Penciptaan kreasi motif batik tidak terbatas pada perorangan namun juga dapat dilakukan oleh lembaga seperti Balai Besar dan Kerajinan Batik (Salma, 2019). Penciptaan bersumber ide dari kesenian daerah seperti Reog Ponorogo sebagai pengembangan batik juga telah dilakukan sebelumnya (Mulyanto dan Hartono, 2018). Mengangkat potensi budaya setempat sebagai ide penciptaan juga pernah dilakukan dengan mengangkat ukiran Bali sebagai inspirasi motif kreasi gitar elektrik" (Yoga dan Eskak, 2015). Aktivitas ini tentu dapat menghidupkan berbagai potensi tanah air sebagai ide penciptaan agar dinamika budaya Indonesia menjadi semakin baik.

Makalah ini kemudian memiliki pertanyaan: bagaimana mengangkat krustasea Arafura sebagai sumber ide untuk pembuatan purwarupa batik yang memiliki karakter?

\section{METODOLOGI PENELITIAN}

Penelitian ini menggunakan pendekatan eksperimental, karena bertujuan menghasilkan produk dalam bentuk desain batik. Kreativitas dan eksperimen adalah inti dari proses perancangan (Hall, 2011). Eksperimen bertujuan untuk mengembangkan serta menguji kemanfaatan dan efektivitas produk (model) yang dikembangkan, baik produk teknologi, material, organisasi, metode, alat-alat, dan sebagainya. Sebagai riset terapan, penelitian pengembangan bertujuan bukan untuk menghasilkan teori. Oleh karena itu, dalam penelitian pengembangan sangat dimungkinkan untuk menggunakan multi pendekatan dan multi metode.

Dalam proses eksperimental ini, dipergunakan model 4-D dari Sivasailam Thiagarajan (1974). Pada model 4-D, Thiagarajan menguraikan dalam bentuk: (1) mendefinisikan;

(2) desain; mengembangkan; dan (4) diseminasi.

\section{Alat dan Bahan}

Alat dan bahan yang dipakai terbagi menjadi dua bagian yaitu bahan dan alat untuk membuat desain dan untuk membuat batik. Alat dan bahan pembuatan desain secara manual adalah kertas gambar, kertas pola, pensil 2B, karet penghapus, spidol hitam kecil, tinta hitam, cat warna, penggaris, kuas, palet cat air, dan meja kaca. Alat dan bahan untuk pembuatan desain dengan komputer adalah set PC grafis, perangkat lunak Coreldraw, pemindai, dan pencetak. 


\section{Lokasi dan Waktu Penelitian}

Lokasi penelitian adalah laboratorium batik, Fakultas Pendidikan Seni dan Desain, Universitas Pendidikan Indonesia, Bandung. Waktu penelitian adalah 2 bulan, mulai Januari - Februari 2019.

\section{HASIL DAN PEMBAHASAN}

\section{Definisi}

Pada tahap awal model 4-D Thiagarajan dilakukan definisi dengan menetapkan konsepsi terhadap obyek eksperimentasi. Tahap pendefinisian dilakukan analisis melalui studi literatur terdahulu (Thiagarajan, 1974).

Definisi krustasea adalah hewan air yang ditemukan di air laut, memiliki cangkang keras, beberapa bagian tubuh mengandung lampiran, bernafas dengan insang, dan memiliki nilai ekonomi tinggi. Sejumlah krustasea yang ditemukan di perairan Arafura dari hasil penelitian oleh Arbi (2008) dapat dilihat pada Gambar 1.

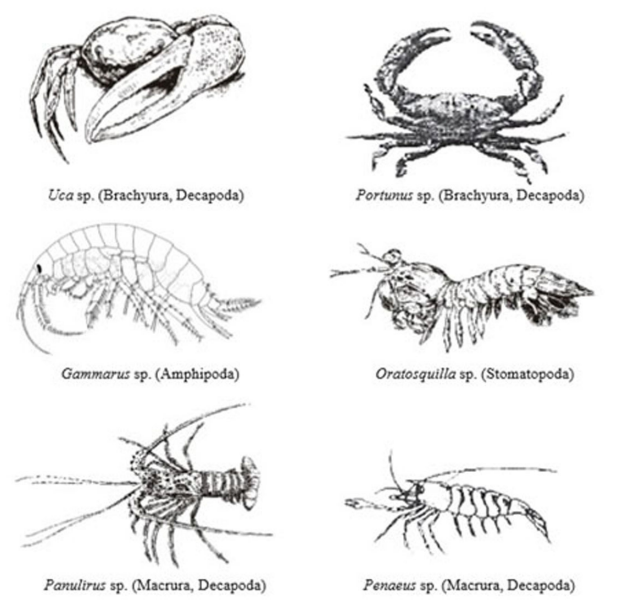

Gambar 1. Aneka Krustasea (Arbi, 2008)

Meskipun sebenarnya ada sangat banyak krustasea yang dapat diangkat secara visual, tetapi pada tahap awal, yang paling dominan adalah Uca sp. (Brachyura,
Decapoda), Portunus sp. (Brachura, Decapoda), Gammarus sp. (Amphipoda), Oratosquilla sp. (Stomatopoda), Panulirus sp. (Macrura, Decapoda) dan Penaeus sp. (Macrura, Decapoda).

Definisi batik adalah teknik menghias permukaan kain dengan cara rintang warna (wax resist). Batik dihasilkan oleh berbagai suku di dunia. Kain batik yang digunakan di pedesaan hingga perkotaan di Indonesia telah lama menjadi bagian penting dalam khazanah busana suku Melayu (Roojen, 2001).

Sejarah panjang rintang warna pada awalnya memakai zat warna alam seperti beras, lilin, lumpur, umbi-umbian yang dilumatkan. Kegiatan ini sudah dilakukan sebelum masehi di Mesir, juga pada masa dinasti T'ang di Cina abad kedelapan masehi. Namun sulit terbantahkan bahwa di Pulau Jawa, batik mencapai puncak pencapaiannya, baik dalam hal motif dan busana yang mengikutinya (Elliott, 2004). Peluang batik sebagai karya dan karsa manusia, dapat terus dikembangkan di wilayah lain termasuk di belahan Indonesia timur seperti Ambon, Papua, termasuk Arafura.

\section{Desain}

Thiagarajan (1974) menyatakan pada tahap desain atau perancangan, peneliti membuat produk awal (prototype) atau rancangan produk. Tahap perancangan pada penelitian ini berupa membuat konsep desain, yang sesuai dengan tahapan pendefinisian yang telah dilakukan sebelumnya. 
Berikut adalah bagan proses desain:

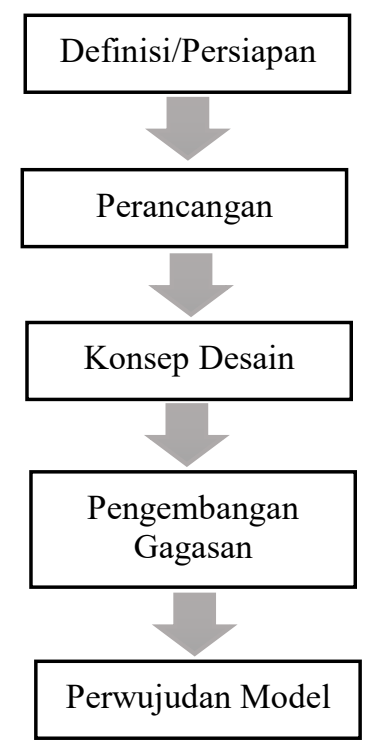

Gambar 2. Bagan Proses Desain

Konsep desain yang diajukan dalam tahap perancangan ini adalah "Biru Lautku". Pemilihan warna biru identik dengan air laut Arafura yang sangat dalam dan kaya akan potensi hasil laut termasuk krustacea. Pertimbangan lain yaitu bahwa warna biru dapat merupakan denotasi terhadap alam bahari.

Unsur lain yang diangkat adalah ide dasar krustasea dan rumput laut (Gelidium $s p$. L) yang banyak ditemukan di pantai laut Arafura. Krustasea Arafura menjadi tujuan pembuatan motif utama batik, sedangkan rumput laut sebagai motif pelengkap.

Tahap berikutnya setelah menetapkan konsep desain adalah pengembangan gagasan. Pada tahap ini, gagasan digambarkan pada helai kertas (Gambar 3). Pengembangan gagasan menjadi sketsasketsa ini dilakukan hingga terpilih gambar yang dinilai terbaik.

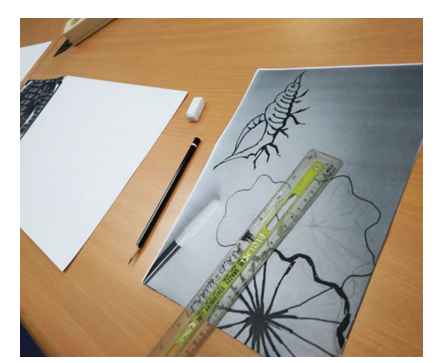

Gambar 3. Eksperimentasi Motif (foto: Wardoyo, 2019)

Pada tahap pengembangan juga dilakukan proses potong dan tempel (Gambar 4). Proses potong dan tempel dilakukan untuk memperoleh komposisi desain yang diinginkan.

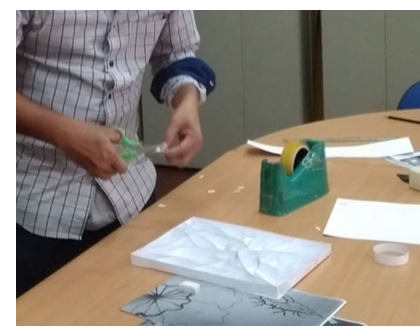

Gambar 4. Eksperimentasi Motif
(foto: Wardoyo, 2019)

Tahap berikutnya adalah menyusun komposisi motif seperti pada Gambar 5. Terdapat dua unsur dalam penyusunan motif, yaitu motif utama dan motif isian. Pemilihan motif utama adalah krustasea, sedangkan motif isian adalah rumput laut (Gelidium sp. L).

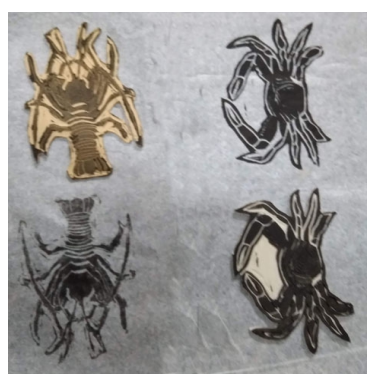

Gambar 5. Komposisi Motif (foto: Wardoyo, 2019) 


\section{Pengembangan}

Tahap pengembangan terbagi atas 2 kegiatan yaitu penilaian dan percobaan pengembangan. Penilaian merupakan cara untuk memvalidasi atau menilai kelayakan rancangan produk. Percobaan pengembangan merupakan kegiatan ujicoba rancangan pada subyek yang sesungguhnya (Thiagarajan, 1974).

Pada tahap pengembangan, dilakukan pengolahan memakai alat komputer, dengan perangkat lunak Coreldraw. Sebelum dilakukan pengolahan, dilakukan pemindaian terhadap desain awal terpilih.

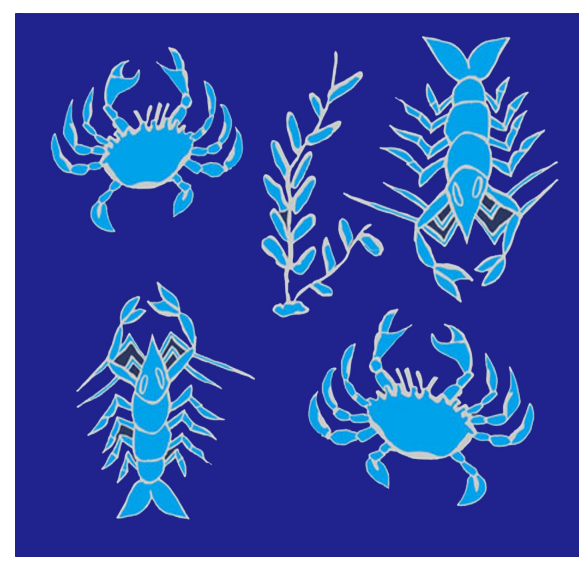

Gambar 6. Pengembangan dengan perangkat komputer (Wardoyo, 2019)

Gambar 6 adalah hasil pengembangan motif menggunakan perangkat lunak Coreldraw. Pengolahan grafis serta pemberian warna dan komposisi secara digital dapat memudahkan dalam proses pengembangan ini.

Tahap berikutnya adalah penerapan pada busana. Tahap ini termasuk pembuatan purwarupa hasil pengembangan gagasan dari bagan proses desain (Gambar 2). Perwujudan purwarupa
(Gambar 6) yang berangkat dari ide krustasea Arafura ditunjukkan pada Gambar 7.

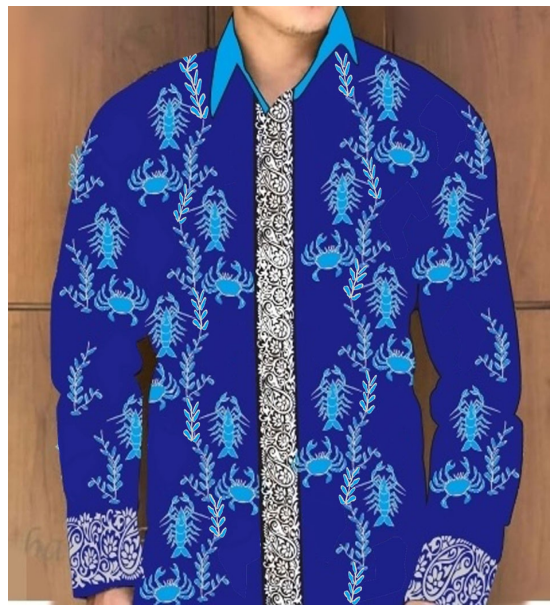

Gambar 7. Perwujudan Purwarupa (Wardoyo, 2019)

\section{Diseminasi}

Proses akhir suatu perancangan adalah diseminasi. Pada tahap ini, menurut Thiagarajan (1974), dilakukan promosi serta ketepatan media promosi. Dalam rancangan ini dipakai media promosi media sosial (Instagram, Facebook, Whatsapp, dan lainnya) serta promosi pameran.

\section{KESIMPULAN DAN SARAN}

Kekayaan alam Indonesia sangat berlimpah. Kekayaan meliputi flora, fauna, adat istiadat, hingga budaya lokal. Pemanfaatan kekayaan Indonesia dapat terus digali, diolah, dan dikembangkan dalam berbagai bentuk, termasuk seni. Pemanfaatan itu memberi nilai tambah sesuai dengan nilai-nilai yang dianut masyarakat. Dalam penelitian ini, biota laut Arafura dieksplorasi, untuk menjadi 
identitas visual wilayah tersebut dan untuk menambah nilai pada produk budaya lokal yang memiliki nilai estetika. Pada akhirnya bisa berkembang menjadi nilai ekonomi.

Batik adalah produk budaya Indonesia yang telah diakui oleh lembaga dunia seperti UNESCO. Batik juga harus tumbuh di berbagai daerah di Indonesia, termasuk di timur, seperti yang terjadi di Merauke, Papua. Laut Aru dan Arafura adalah daerah yang sangat kaya akan sumber daya alam dan sumber daya manusia yang dapat berkontribusi untuk mengembangkan keterampilan membatik ini. Mengangkat sumber daya alam lokal sebagai sumber gagasan penciptaan dapat memberikan nilai tambah bagi budaya dan pariwisata setempat.

Penciptaan purwarupa busana motif batik berdasarkan sumber ide krustasea Arafura ini dapat menjadi satu pilihan alternatif baru, selain dapat membuka potensi ekonomi biota laut tidak sebatas produk konsumsi. Potensi kreatif penciptaan berdasarkan krustasea Arafura diharapkan dapat memperkaya khasanah busana sebagai salah satu artefak budaya.

\section{REKOMENDASI}

Hasil dari eksperimen ini adalah purwarupa pakaian bermotif batik cap krustasea Arafura. Rekomendasi ditujukan kepada kepala daerah setempat, Arafura, Papua, Ambon, dan sekitarnya untuk dapat menciptakan pakaian berciri khas lokal untuk kemudian dapat mengangkat citra wilayah dan ekonomi masyarakat setempat. Rekomendasi juga diberikan kepada Badan Ekonomi Kreatif untuk mengokohkan aneka biota laut yang dapat diolah sebagai sumber ide penciptaan produk-produk lain seperti kriya, sebagai cenderamata dari wilayah Timur Indonesia.

\section{UCAPAN TERIMA KASIH}

Ucapan terimakasih penulis sampaikan kepada Departemen Pendidikan Seni Rupa dan Desain, Universitas Pendidikan Indonesia, Bandung dan Fakultas Seni Rupa dan Desain, Universitas Trisakti, Jakarta, atas dukungan penggunaan laboratorium dan fasilitas kerja selama proses eksperimentasi.

\section{KONTRIBUSI PENULIS}

Kontributor utama pada tulisan ini adalah Farid Abdullah, sedangkan Bandi Sobandi dan Bambang Tri Wardoyo merupakan kontributor anggota.

\section{DAFTAR PUSTAKA}

Arbi, U.Y. (2008). Burung Pantai Pemangsa Krustasea. Jurnal Oseana, XXXIII, 2(1), 1-8.

Baransano, H.K., Mangimbulude, J. (2011). Eksploitasi dan Konservasi Sumberdaya Hayati Laut dan Pesisir di Indonesia, Jurnal Biologi Papua, 3(1), 39-45.

Darsono, P. (1999). Pemanfaatan Sumber Daya Laut dan Implikasinya Bagi Masyarakat Nelayan, Jurnal Oseana, XXIV(4), 1-9.

Eskak, E., Widiyastuti, R. (2019). Seni Rias Suku Dani dalam Penciptaan Cenderamata Khas Papua dari Bahan Bambu, Dinamika Kerajinan dan Batik, 30(1), 35-46.

Hall, A., (2011). Experimental Design: Design Experimentation. Design Issues, 27(2), 1726.

Himawan, W. (2014). Citra Budaya Melalui Kajian Historis dan Identitas: Perubahan Budaya Pariwisata Bali Melalui Karya Seni Lukis. Journal of Urban's Society Art, 1(1), 74-88. 
Hoek, F. dkk. (2015). Potensi Sumber Daya Udang Penaeid di Perairan Kepulauan Aru Bagian Timur Sub Wilayah Aru dan Sekitarnya, Jurnal Airaha, 4(1), 12-20.

Ibrahim, Y. (2007). Island Community in Development Era: Are Marginalised or Had Marginalised?" Akademika, Journal of Southeast Asia Social Sciences and Humanities, 70(1), 57-76.

Martin, J.W. dan Davis, G.E. (2001). An Updated Classification of the Recent Crustacean, Natural History Museum of Los Angeles County Contributions in Science, 39(1), 1124.

Moersid, A.F. (2013). Re-Invensi Batik dan Identitas Indonesia dalam Arena Pasar Global. Jurnal Ilmiah Widya, 1(2), 121-128.

Monintja, D.R. dkk. (2006). Perspektif Pengelolaan Perikanan Tangkap Laut Arafura. Departemen Pemanfaatan Sumberdaya Perikanan, Fakultas Perikanan dan Ilmu Kelautan, Institut Pertanian Bogor.

Mulyana, R. (2012). Keberlanjutan Perikanan Skala Besar di Laut Arafura. Jurnal Pemanfaatan Sumberdaya Perikanan, 20(1), 35-43.

Mulyanto dan Hartono, L. (2018). Kesenian Reog sebagai Sumber Ide Pengembangan Desain Motif Batik Ponorogo, Dinamika Kerajinan dan Batik, 35(1) 33-44.

Roojen, P. (2001). Batik Design. Singapore: The Pepin Press.

Salma, I.R. (2019). Review: Pengembangan Motif Batik Khas Daerah di Balai Besar Kerajinan Batik. Dinamika Kerajinan dan Batik, 36(2), 149-162.

Sedyawati, E. (2014). Laut, dalam Kebudayaan di Nusantara; dari Keris, Tortor, sampai Industri Budaya. Depok: Komunitas Bambu.

Thiagarajan, S. dkk. (1974). Instructional Development for Training Teachers of Exceptional Children: A Sourcebook. Minneapolis: Leadership Training Institute/Special Education, University of Minnesota.

Wedjatmiko. (2010). Beberapa Aspek Biologi Ikan Demersal dan Krustasea di Perairan
Arafura, Jurnal Perikanan (J. Fish Sci.) XII (1), 35-42.

Yoga, W.B.S., Eskak, E. (2015). Ukiran Bali dalam Kreasi Gitar Elektrik, Dinamika Kerajinan dan Batik, 32(2), 117-126. 